\title{
Necessary and Sufficient Conditions for Agribusiness Success of Small-scale Farming Systems in Northern Vietnam
}

\author{
Tuan M. Ha ${ }^{1}$, Ockie J. H. Bosch ${ }^{1}$, Nam C. Nguyen ${ }^{1}$ \\ ${ }^{1}$ Systems Design and Complexity Management Alliance (SDCM), The University of Adelaide Business School, \\ Adelaide, Australia \\ Correspondence: Tuan M. Ha, Systems Design and Complexity Management Alliance (SDCM), The University of \\ Adelaide Business School, Adelaide, Australia
}

Received: April 24, 2015 Accepted: May 11, 2015 Online Published: May 13, 2015

doi:10.11114/bms.v1i2.820

URL: http://dx.doi.org/10.11114/bms.v1i2.820

\begin{abstract}
This study was conducted in Haiphong (Vietnam) during 2013-2014 to analyse the requirements for the success of small-scale agribusinesses. Following two baseline studies on the current state of the local farming systems and market situations, various stakeholders were engaged in a number of workshops with support of a causal loop diagram (CLD) modelling tool to redefine the pre-requisites for agribusiness success and their interplays. As a result, multi-stakeholder collaboration and government support via its policies and development programs were identified as the necessary conditions for success. Nonetheless, strengthening the capacity of local cooperatives and investing in human and social capitals are of equal importance as sufficient conditions, which generate multiple benefits towards achieving agribusiness success. Values of full participation by all stakeholders and the use of the CLD in defining systemic interventions are also discussed.
\end{abstract}

Keywords: agribusiness, contract farming, market linkages, small farmers, systemic interventions

\section{Introduction}

The majority of the world's poor is smallholder farmers who are reliant on agricultural production. Securing market access for agricultural produce has been identified as one of the most important strategies towards rural development and poverty alleviation (Fischer \& Qaim, 2012).

Sharing common characteristics with many other developing countries in the world, Vietnam is a poor agriculture-based economy (Bosch, Nguyen, Ha, \& Banson, 2015; Ha, Bosch, \& Nguyen, 2015b, 2015c) with 75\% of the population residing in rural areas (Wijk \& Everaarts, 2007), with nearly 60\% dependent on agriculture (Ha, Bosch, \& Nguyen, 2015a; Hoang, 2011). Agricultural production is typically in the form of small-scale farming systems in all regions (Dixon, Gibbon, \& Gulliver, 2001; MacAulay, 2006; Tisdell, 2009; Wijk \& Everaarts, 2007). The country possesses around 10 million small farms, ranked fifth in number of small farms in Asia and the Pacific region (Hazell \& Rahman, 2014, pp. 69-70). The main income sources of small farmers are derived from crops and livestock production (Ha, et al., 2015b).

Due to a number of reasons such as small areas of production land, limited skills and resources and a lack of market information, the Vietnamese smallholder farmers are facing various challenges in production, market access, producer trader relationships (Bosch, et al., 2015; Ha, Bosch, \& Nguyen, 2014; Ha, et al., 2015a, 2015b), and competitiveness of agricultural produce (Jabbar \& Akter, 2008; Lapar et al., 2006). Especially after the country joined the World Trade Organization in 2007, land fragmentation, small-scale production, high production costs, poor and inconsistent quality of produce have become major obstacles in agribusiness (Dung \& Jenicek, 2008; Vo-Tong, 2002).

In addition, inappropriate and 'top-down' approaches in policies of central and local governments have been reported to induce exclusion of small farmers from extension services (Beckman, 2001); whereas, their market outlets are mainly dependent on private traders that are insecure and less profitable (Ha, et al., 2015a, 2015b). These factors would cause them to be more vulnerable, falling into a vicious cycle of poverty and further extending the urban-rural income gap.

The purpose of this paper is therefore to analyse the requirements for small-scale agribusiness success through a case study in Haiphong province (northern Vietnam), providing grounds for systemic interventions to support local producer 
groups in sustaining their livelihoods and incomes. In addition to the other conditions identified as necessary for successful agribusinesses such as contract farming, multi-actor collaboration, improved transparency and accountability, and enhanced support from the local government (Bosch, et al., 2015; Ha, et al., 2015a, 2015b, 2015c), the authors argue that reinforcing and investing in social and human capitals, and institutional strengthening for local producer groups are of equal importance as the sufficient conditions in forming collective actions and many other intangible outcomes for viable agribusiness in rural Haiphong. This is consistent with Heijden and Vink (2013) who asserted that favourable policies and external support are "necessary", but they are insufficient to gain access to modern supply chains for smallholder farmers.

\section{Literature Review}

\subsection{Barriers to Market Access of Small Farmers}

Many studies have highlighted various barriers to market access for small farmers around the world (e.g. Barrett et al., 2012, pp. 78-79; Biénabe \& Sautier, 2005; Fischer \& Qaim, 2012; Hazell \& Rahman, 2014), making them excluded from the modern market chains (Al-Hassan, Sarpong, \& Mensah-Bonsu, 2006; Hazell, 2005).

Heijden and Vink (2013) provide an overview of five main hindrances to market access of smallholder farmers in developing countries. Those include: lack of market information; poor bargaining power and fragmented production; poor infrastructure; limited essential financial, physical and human capitals; and limited producer-buyer relationship and trust. Other contributing factors comprise geographical, biophysical and institutional constraints (limited access to resources) (Barrett, et al., 2012), subsistence production habits (Bijman, 2008), and poor competitiveness of produce (Biénabe \& Sautier, 2005; Hazell, 2005). These hamper them from pursuing their livelihood strategies.

Transformations of agrifood systems have recently been evident in the developing world with an increasing involvement of supermarkets in food retailing. These have certainly created significant challenges to smallholder farmers in participating in the mainstream supply systems (Louw, Jordaan, Ndanga, \& Kirsten, 2008). These authors also illustrated different market outlet options and ease of access (Figure 1) where smallholders are mainly restricted to traditional markets.

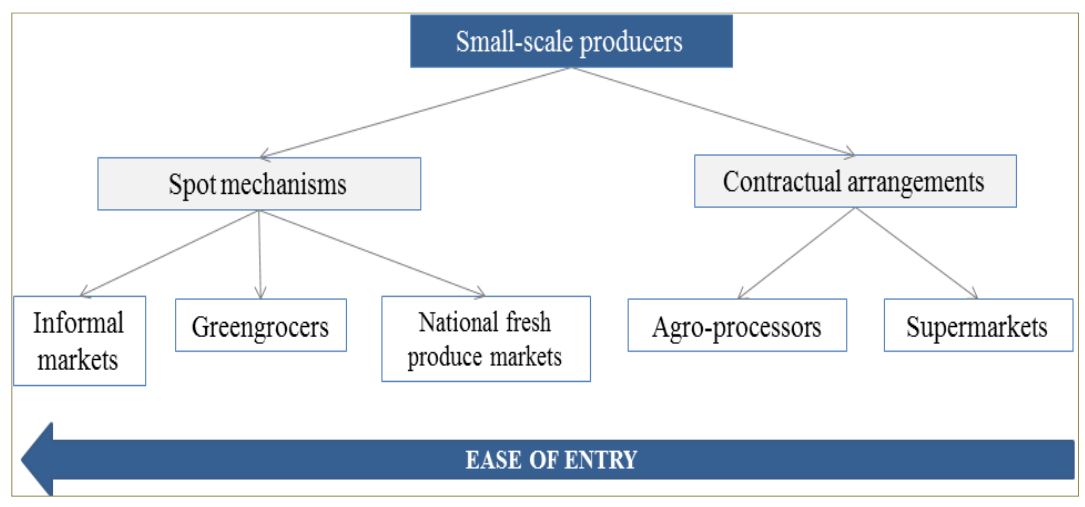

Figure 1. Market access options and ease of entry by small farmers (Adapted from Louw, et al., 2008).

In fact, agribusiness companies are not interested and are incapable of doing business with individual smallholders (Hazell, 2005). According to Al-Hassan, et al. (2006), the requirements of agribusinesses in terms of product volume, consistency of quality and regular delivery are amongst the contributing factors that make small farmers left behind in the modern supply chains.

To sustain a foothold for small farmers in the emerging modern markets, a number of measures should be taken into account where concerted efforts by multi-actors are required. These are discussed in detail in the sections below.

\subsection{Success Factors for Small-scale Agribusiness}

Policies in favour of small-scale agribusinesses are of crucial importance to include small farmers in the emerging agrifood systems (Louw, et al., 2008, p. 11). Some examples of such policies include enhancing research and improving extension to diffuse advanced technologies appropriate to small farmers; providing market information and risk management aids (e.g. safety net programs, credit and agricultural insurance, etc.) (Hazell, 2005); enabling access to lands, land consolidation for large-scale production and investing in production and rural infrastructure (Bosch, et al., 2015; Ha, et al., 2015a, 2015c); offering favourable loan policies for local agribusinesses (Ha, et al., 2015a); and supporting marketing and quality control of clean produce (Ha, Bosch, \& Nguyen, 2015d).

Multi-actor collaboration plays an equally important role in eliminating the aforementioned obstacles faced by small 
farmers in the supply chain, creating collective actions to improve competitiveness of produce and thus their participation in the modern agrifood system (Louw, et al., 2008). This form of public-private partnership (PPP) has been proven a viable strategy to sustain market access for smallholder farmers (Benziger, 1996; Biénabe \& Sautier, 2005; Louw, et al., 2008). The PPP also enables small farmers to gain access to niche organic and fair-trade markets (Biénabe \& Sautier, 2005), which substantially benefit farmers in developing countries, as they can receive higher prices from their participation (Hazell \& Rahman, 2014, p. 187). In addition, market actor linkages have been affirmed as amongst the key interventions to secure market access and improve incomes for smallholders (Bosch, et al., 2015; Ha, et al., 2014, 2015c, 2015d). These coalitions provide opportunities for contractual arrangements between local producer groups and agribusinesses (Ha, et al., 2015a).

Recent studies have highlighted the essential role of contract farming (CF) in domestic and export markets in developing countries (Barrett, et al., 2012; Kirsten \& Sartorius, 2002; Prowse, 2012) and in Vietnam (Catelo \& Costales, 2008; Nga, Ha, \& Hai, 2011; Saigenji \& Zeller, 2009). Bellemare (2012) found a significant relationship between participation to CF and incomes of small farmers in Madagascar. In which, a 1-percent increase in the probability of participation in CF resulted in a 0.5 -percent rise in household income.

Although the above-mentioned factors are essential to support smallholder farmers in dealing with the market access challenges, forming and strengthening local producer groups (cooperatives), human and social capitals are required as the "sufficient conditions" to achieve sustainable small-scale agribusiness. This is because CF is not possible when produce is supplied by individual farmers in small volume, different times of delivery and inconsistent quality (Bosch, et al., 2015; Ha, et al., 2015a, 2015d). Whereas, business companies tend to sign contracts with large-scale producers as those can more easily meet their purchase orders and requirements (Blandon, Henson, \& Cranfield, 2009; Costales \& Catelo, 2008). Forming cooperatives is therefore needed to address the challenge.

Besides, forming and enhancing capacity of existing producer groups can achieve many other tangible and intangible benefits for smallholders such as ease of access to technologies, services and markets (Hazell, 2005; Thapa \& Gaiha, 2011), reduced transaction costs, increased productivity, quality, competitiveness, economies of scale (Biénabe \& Sautier, 2005; Ha, et al., 2015b; Hazell, 2005), enhanced bargaining power and more focused technical and institutional assistance (Ha, et al., 2015b; Lapar, et al., 2006). Producer groups also help to reinforce farmers' position in the supply chains, while these local organizations can play an advocacy role to leverage policies in favour of smallholder agriculture (Louw, et al., 2008).

Investments in human and social capitals have also been proven as amongst the effective strategies that will enhance knowledge, production and management skills for farmers, while fostering agribusiness through improving producer-buyer relationships and trust (Flora, Bregendahl, \& Renting, 2012; Ha, Bosch, \& Nguyen, 2015e).

Though there have been a large number of studies on defining interventions to improve and sustain market access for small farmers around the world, little research has been conducted to explore the "systemic relationships" and interplays between strengthening the capacity of local producer groups and other operational and agribusiness factors. This study therefore contributes to the knowledge gap towards a better understanding of the causal relationships and thus the identification of systemic interventions that are required for successful small-scale agribusinesses in the research area.

\section{Approach and Methods}

\subsection{Study Location and Target Groups}

This study was conducted during 2013-2014 in Haiphong, one of the typical lowland production areas of the Red River Delta of Northern Vietnam.

The target groups include 35 local small farmers of four rural districts of Haiphong and representatives of relevant departments and organisations, including the Department of Agriculture and Rural Development (DARD), Department of Planning and Investment (DPI), the extension centre, district extension stations, service and input providers, agribusiness companies in Haiphong and nearby provinces (a total of 75 participants).

\subsection{Approach and Process Steps}

Following the baseline studies for understanding the current state of the small-scale farming systems and market situations in the area (Ha, 2013, 2014c; Ha, et al., 2015b), a number of workshops and focus group discussions were held with the participation of the above-mentioned stakeholders to understand the key issues in more depth and to seek appropriate interventions in addressing the barriers to market access.

To avoid the power influence amongst the stakeholders and to understand insights of the market access issue, a number of separate dialogues and workshops were held with different groups (i.e. government organizations, small farmers, service and input providers, and agribusiness companies). Results of the dialogues and workshops were then presented 
again for feedback, addition and validation through a plenary workshop.

Key members of the stakeholder groups were invited to participate in a small group discussion to define relationships amongst different variables (factors), which were defined from the previous workshops. Vensim ${ }^{\circledR}$ software (Ventana ${ }^{\circledR}$, 2011) was employed by the facilitators to develop a causal loop diagram (systems model) that shows causal links amongst the variables and potential factors (leverage points) for systemic interventions. The formulated model was then presented again at a plenary workshop for feedback and modifications by all the stakeholders.

\section{Results and Discussion}

\subsection{Key Requirements for the Success of Small-scale Agribusinesses in Haiphong}

The preliminary findings showed that the following priorities should be implemented in a coordinated manner to improve the rural lives in Haiphong (Ha, et al., 2015a):

1. Improve income via enhanced market access, reduced production costs, and available secondary jobs;

2. Strengthen production efficiency for reduced workload via supporting the availability of production devices, capacity building, production infrastructure and efficient service groups;

3. Form cooperatives/producer groups for improved market actor linkages, reduced production costs and improved product quality;

4. Improve health via reducing workload, improving eco-friendly production facilities and practices, rural hygiene and access to healthcare services.

These factors were found to have strong interrelationships, which together determine the level of the quality of life of local small farmers. It is apparent that improving market access through stronger linkages among market actors is a "necessary condition" to improve income. This can be seen as the most urgent need of the smallholder farmers, which helps to solve the other issues (i.e. heavy workload and poor health). Whereas, forming and strengthening existing producer organisations are required as a "sufficient condition" to sustain market linkages.

The current situation in Haiphong reveals a number of bottlenecks that hinder market linkage endeavours. These include: fragmented and spontaneous production amongst individual households, poor coordination and performance of the existing cooperatives, low awareness and short-sighted visions amongst individual farmers, and unfavourable policies for local agribusinesses and cooperatives. As a result, companies are hesitant to sign contracts with local farmers (Ha, et al., 2015a).

Results of the follow-up workshops with separate groups of stakeholders are presented in Table 1. Interestingly, there were high similarities in the opinions between smallholder farmers and other stakeholders. The mentioned requirements for improving market linkages include not only government interventions and the forming and strengthening of cooperatives, but also a need for trust building between agribusinesses and local farmers.

Table 1. Discussion results on how to enhance market linkages and performance of local producer groups (cooperatives) in Haiphong

\begin{tabular}{|c|c|c|}
\hline & Other stakeholders ${ }^{(*)}$ & Small farmers \\
\hline \multicolumn{3}{|c|}{ Question 1 - How to improve collaboration between companies and farmers? } \\
\hline 1. & $\begin{array}{l}\text { Government interventions: introduce potential companies to farmers; } \\
\text { develop large-scale production zones; offer supporting policies for local } \\
\text { companies (favourable credit schemes); }\end{array}$ & $\begin{array}{l}\text { 1. Trust building \& ensure the liability/commitment by both } \\
\text { sides; }\end{array}$ \\
\hline 2. & $\begin{array}{l}\text { Develop producer groups and enhance their capacity and commitment to } \\
\text { fulfil the requirements of the contracts; }\end{array}$ & $\begin{array}{l}\text { 2. Farmers (cooperatives): ensure produce quality, sufficient } \\
\text { production volume (large scale production), and } \\
\text { long-term vision. }\end{array}$ \\
\hline 3. & Build trust for both companies and producers, and ensure mutual benefits. & $\begin{array}{l}\text { 3. Government support: seed funding, legal regulations to } \\
\text { protect farmers, enhance the linkage. }\end{array}$ \\
\hline \multicolumn{3}{|c|}{ Question 2 - How can producer groups (cooperatives) be more effective? } \\
\hline & $\begin{array}{l}\text { Cooperatives/producer groups should have effective management units } \\
\text { with capable leaders to formulate operation regulation and management } \\
\text { plans; Promoting experience sharing among producer groups/cooperatives. }\end{array}$ & $\begin{array}{l}\text { 1. Having effective (capable) management units to develop } \\
\text { good plans and operation regulations; adopting large } \\
\text { scale production; mobilising capital; }\end{array}$ \\
\hline & $\begin{array}{l}\text { Supporting policies such as: capacity building for leaders and members of } \\
\text { the cooperatives; Providing "seed funding" at the initial operation stage } \\
\text { and access to credit; }\end{array}$ & $\begin{array}{l}\text { 2. Developing linkages with companies and facilitating } \\
\text { strong member commitment and discipline; }\end{array}$ \\
\hline & Enhance linkages with companies for contract farming. & $\begin{array}{l}\text { 3. Government's support: establishing specialised } \\
\text { cooperatives, supporting capacity building, access to } \\
\text { markets, capital, production inputs, infrastructure and } \\
\text { production devices. }\end{array}$ \\
\hline
\end{tabular}

${ }^{(*)}$ Notes: Other stakeholders (left column) include representatives of DARD, DPI, the extension network, companies, service and input providers.

Besides possible government support in terms of favourable policies, engagement of potential companies, production 
devices and infrastructure, and access to resources, the participants were also aware that enhancing "bridging social capital" through better linkages with market actors, while reinforcing human (local leadership) and bonding social capitals (relationship, trust, and shared vision) amongst cooperative members are of equal importance. These would all contribute to strengthening the capacity of local producer groups to address the market access challenge.

Results of mind mapping by all the participants on ways to improve producer groups' performance also reveal key factors, their relationships and more insights of where actions should be taken. Improving capacity for the management unit is essential as it will bring about multiple effects (Figure 2).

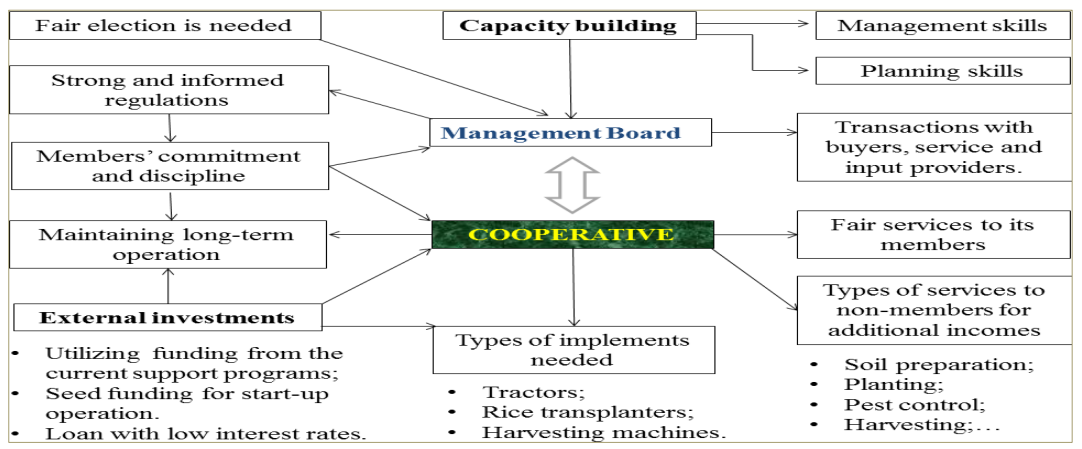

Figure 2. Mind mapping of ways to improve producer groups' performance

The plenary discussions between all stakeholders provided a 'big' picture on how to achieve agribusiness success of the small-scale farming systems in rural Haiphong (Figure 3). These systems comprise the required elements of production services, organization and market access that should be addressed simultaneously in a coordinated manner.

\begin{tabular}{|l|l|l|}
\hline \multicolumn{1}{|c|}{ AGRI-BUSINESS SUCCESS } \\
\hline Production Inputs
\end{tabular}

Figure 3. Requirements for agribusiness success in the rural districts of Haiphong - Vietnam At the farm level, the following requirements and process steps should be met and conducted to realise the expected outcomes (i.e. strengthened local cooperatives for improved market linkages and access) (Figure 4).

\begin{tabular}{|c|c|c|}
\hline INPUTS & PROCESS & OUTCOMES \\
\hline $\begin{array}{l}\text { - Capacity building for } \\
\text { producer groups' } \\
\text { management units and } \\
\text { individual farmers; } \\
\text { - Farmers' commitment \& } \\
\text { contribution; } \\
\text { - Seed funding and loans } \\
\text { by the local government; } \\
\text { - Access to information, } \\
\text { services and production } \\
\text { inputs. }\end{array}$ & $\begin{array}{l}\text { - Land consolidation for the ease } \\
\text { of mechanization and } \\
\text { synchronous production; } \\
\text { - Production planning \& } \\
\text { organization; } \\
\text { - Sharing of experience \& } \\
\text { production devices; } \\
\text { - Production services; } \\
\text { - Monitoring of progress \& } \\
\text { - } \text { Product branding \& marketing. }\end{array}$ & 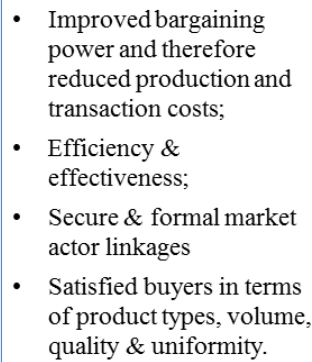 \\
\hline
\end{tabular}

Figure 4. Institutional strengthening for local cooperatives' management units to be effective production (services) organizations.

Even though the above outcomes provide clear benefits in strengthening local producer groups to achieve success in agribusinesses in Haiphong, they do not show systemic interplays between the proposed intervention (strengthening capacity of local cooperatives) and other factors towards the defined goal. Therefore, more in-depth analyses using a 
systems tool were carried out with the participation of the key partners. These would help to further convince the local government and possible donors for effective funding and support to develop viable producer groups (see details below).

\subsection{Multiple Systemic Benefits of Capacity Building for Local Producer Groups}

Outcomes of the facilitated group discussions by key representatives of all the stakeholders were finally confirmed and refined through a plenary workshop. A causal loop diagram (CLD) was developed showing a dynamic relationship amongst the defined variables (factors). Interventions to enhance the capabilities for producer groups were stated to bring about "multiple" effects (Figure 5), which could eventually improve the income for participating small farmers.

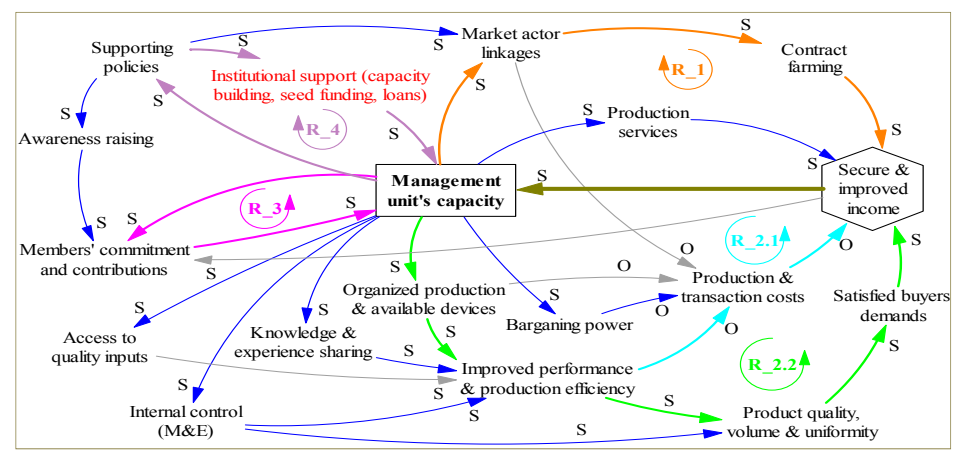

Figure 5. CLD modelling for improving performance of local cooperatives through institutional support. Notes: $\mathrm{S}$ Same direction; O - Opposite direction; R - Reinforcing (loops). Only important loops are highlighted for clarity and ease of tracking.

There are multiple reinforcing loops formed between the two main variables, "management unit's capacity" and "secure and improved income". Besides the government's support in engaging potential market actors, the improved capacity of local cooperatives' management units was said to enhance their power to create and build the relationships with other actors in the market chains (bridging social capital). These create a possibility to sign formal supply contracts, and thus more secure and improved incomes (financial capacity) for the cooperatives and participating members. The latter can be seen as an incentive to further invest resources in improving management capacity (reinforcing loop R_1, Figure 5). In turn, this improved capacity reinforces its power (political capital) to leverage policies in supporting smallholder agriculture (loop R_4, Figure 5). These outcomes are consistent with findings of Louw, et al. (2008).

The improved financial and management standing of local groups, through government and donor support, and contributions by members, would lead to more organised production and availability of production implements. These would result in improved production performance and efficiency. Thus, reduction of production costs and increase in product yields and quality are expected, which finally would generate higher income (loops R_2.1 and R_2.2, Figure 5). This is also a source for motivating members' commitment and contributions to the cooperatives (loop R_3, Figure 5).

In addition, the enhanced capacity of cooperatives enables them to access quality production inputs and services, facilitating sharing of production knowledge and experience. Both these contribute to improved production performance and efficiency. As stated in Figure 2, ownership of machinery can enable the cooperatives to provide production services to non-members as a way to generate additional income and thus to maintain their viable operation.

Given the strict food safety requirements of buyers in recent years (Ha, 2011, 2014a, 2014b), internal control of compliance to production guidelines amongst individual members are crucial (Ha, et al., 2015d). Hence, management units of the cooperatives play an important role in this regard to ensure quality produce that will meet the requirements of buyers (Figure 5).

\section{Conclusion}

This paper has presented an overview of the drivers and barriers to market access of small farmers in developing countries and an in-depth analysis of the requirements to address the current challenges faced by farmers in small-scale farming systems in Haiphong, Vietnam. Overall, concerted efforts by multi-actors are essential to achieve secure market access for the target group. Full participation by diverse stakeholders enables an in-depth understanding of the context, and a complete view of the current issues from different angles. The CLD model helps to define causal relationships amongst the defined factors and their impacts on the success of small-scale agribusiness. It also provides a basis for defining appropriate systemic interventions to support local producer groups in sustaining their livelihoods and incomes via improved market access.

This study also confirmed that multi-actor partnerships and government support through policies and development 
programs are highly necessary. However, it cannot guarantee the success of small-scale agribusinesses unless the sufficient conditions are met. That is, strengthening the capacity of local producer groups and investing in human and social capitals are required to address context-specific needs, and to facilitate collective actions and ownership of their livelihood development strategies towards a sustainable future.

\section{Acknowledgement}

The authors would like to express the great gratitude to the Bill \& Melinda Gates Foundation for providing funding (through the Foundation's Grand Challenges Explorations initiatives) to make this research possible. We are very grateful to the Haiphong People's Committee, Department of Agriculture \& Rural Development, the Extension Centre, Department of Planning \& Investment, Department of Statistics and the district extension network for their continuous cooperation and valuable support. A special 'thank you' goes to all the women participants of Kien Thuy, Vinh Bao, An Lao, and Tien Lang districts for their time and valuable contribution to this research.

\section{References}

Al-Hassan, R. M., Sarpong, D. B., \& Mensah-Bonsu, A. (2006). Linking smallholders to markets: International Food Policy Research Institute, Ghana Strategy Support Program.

Barrett, C. B., Bachke, M. E., Bellemare, M. F., Michelson, H. C., Narayanan, S., \& Walker, T. F. (2012). Smallholder participation in contract farming: Comparative evidence from five countries. World Development, 40(4), 715-730. http://dx.doi.org/10.1016/j.worlddev.2011.09.006

Beckman, M. (2001). Extension, poverty and vulnerability in Vietnam Country Study for the Neuchatel Initiative. London: ODI/Swedish University of Agricultural Sciences.

Bellemare, M. F. (2012). As you sow, so shall you reap: The welfare impacts of contract farming. World Development, 40(7), 1418-1434. http://dx.doi.org/10.1016/j.worlddev.2011.12.008

Benziger, V. (1996). Small fields, big money: Two successful programs in helping small farmers make the transition to high value-added crops. World Development, 24(11), 1681-1693. http://dx.doi.org/10.1016/0305-750X(96)00070-8

Biénabe, E., \& Sautier, D. (2005). The role of small scale producers' organizations to address market access. Paper presented at the International Seminar Beyond Agriculture: Making Markets Work for the Poor, London, UK.

Bijman, J. (2008). Contract farming in developing countries: An overview of the literature. Working Paper, (pp. 1-28). Wageningen: Wageningen University, Department of Business Administration.

Blandon, J., Henson, S., \& Cranfield, J. (2009). Small - scale farmer participation in new agri - food supply chains: Case of the supermarket supply chain for fruit and vegetables in Honduras. Journal of International Development, 21(7), 971-984. http://dx.doi.org/10.1002/jid.1490

Bosch, O. J. H., Nguyen, N. C., Ha, T. M., \& Banson, K. E. (2015). Using a systemic approach to improve the quality of life for women in small-scale agriculture: Empirical evidence from Southeast Asia and Sub-Saharan Africa. Paper presented at the 3rd International Symposium on Advances in Business Management Toward Systemic Approach, 21-23. Perugia, Italy. Dominici et al. (2015) BoA-B.S.LAB-2015: 280-285.

Catelo, M. A. O., \& Costales, A. (2008). Contract farming and other market institutions as mechanisms for integrating smallholder livestock producers in the growth and development of the livestock sector in developing countries Pro-poor Livestock Initiative. Rome: Food and Agriculture Organization.

Costales, A., \& Catelo, M. (2008). Contract farming as an institution for integrating rural smallholders in markets for livestock products in developing countries:(I) Framework and applications: PPLPI Research Report.

Dixon, J. A., Gibbon, D. P., \& Gulliver, A. (2001). Farming systems and poverty: improving farmers' livelihoods in a changing world: FAO.

Dung, L. V., \& Jenicek, V. (2008). Challenges with Vietnamese agricultural products joining WTO. Agricultura tropica et subtropica, 41(2), 80-83.

Fischer, E., \& Qaim, M. (2012). Linking smallholders to markets: determinants and impacts of farmer collective action in Kenya. World Development, 40(6), 1255-1268. http://dx.doi.org/10.1016/j.worlddev.2011.11.018

Flora, C. B., Bregendahl, C., \& Renting, H. (2012). Collaborative Community-supported Agriculture: Balancing Community Capitals for Producers and Consumers. Int. J. of Soc. of Agr. \& Food, 19(3), 329-346.

Ha, T. M. (2011). Production of safe vegetables in Thai Nguyen province-Technical report. Thai Nguyen: Australia Award Alumni Program - Small Grant Scheme No. 16.

Ha, T. M. (2013). Current situation of the women smallholder farmers in rural Haiphong, Vietnam: A baseline survey. 
Haiphong, Vietnam: The University of Adelaide Business School in collaboration with Haiphong Department of Agriculture and Rural Development.

Ha, T. M. (2014a). Establishing a transformative learning framework for promoting organic farming in Northern Vietnam: a case study on organic tea production in Thai Nguyen province. Asian Journal of Business and Management, 2(03), 202-211.

Ha, T. M. (2014b). A Review on the Development of Integrated Pest Management and Its Integration in Modern Agriculture. Asian Journal of Agriculture and Food Sciences, 2(04), 336-340.

Ha, T. M. (2014c). Working report on a market survey of the main agricultural produce in Haiphong. Haiphong, Vietnam: The University of Adelaide Business School in collaboration with Haiphong Extension Center.

Ha, T. M., Bosch, O. J. H., \& Nguyen, N. C. (2014). Applying an evolutionary learning laboratory approach for improving the quality of life for women smallholders in the Red River Delta of Vietnam. Paper presented at the European Meetings on Cybernetics and Systems Research (EMCSR), 21-25 April 2014, Vienna, Austria. In Wilby et al. 2014 (Eds.) BoA-EMCSR-2014: 136-143.

Ha, T. M., Bosch, O. J. H., \& Nguyen, N. C. (2015a). Defining the real needs of women smallholders in Vietnam: the importance of grassroots participation and multi-stakeholder collaboration. International Journal of Business and Management Review 3(2), 35-58.

Ha, T. M., Bosch, O. J. H., \& Nguyen, N. C. (2015b). Establishing and Evolutionary Learning Laboratory for improving the quality of life of Vietnamese women in small-scale agriculture: Part I - The current situation. Journal of Systems Research and Behavioural Sciences, In Press.

Ha, T. M., Bosch, O. J. H., \& Nguyen, N. C. (2015c). Establishing and Evolutionary Learning Laboratory for improving the quality of life of Vietnamese women in small-scale agriculture: Part II - Systemic interventions. Systems Research and Behavioral Science In Press.

Ha, T. M., Bosch, O. J. H., \& Nguyen, N. C. (2015d). Systemic interventions addressing the market access challenges of smallholder vegetable farmers in Northern Vietnam. International Journal of Markets and Business Systems, 1(01), (In Press, early online view: http://www.inderscience.com/info/ingeneral/forthcoming.php?jcode=ijmabs).

Ha, T. M., Bosch, O. J. H., \& Nguyen, N. C. (2015e). Using the community capitals framework for resource mapping and mobilisation toward sustainable community development: a case study on improving the quality of life of Vietnamese women farmers. (forthcoming).

Hazell, P. B. (2005). Is there a future for small farms? Agricultural Economics, 32(s1), 93-101. http://dx.doi.org/10.1111/j.0169-5150.2004.00016.x

Hazell, P. B., \& Rahman, A. (Eds.). (2014). New Directions for Smallholder Agriculture. Oxford: Oxford University Press. http://dx.doi.org/10.1093/acprof:oso/9780199689347.001.0001

Heijden, T. v. d., \& Vink, N. (2013). Good for whom? Supermarkets and small farmers in south africa-a critical review of current approaches to increasing access to modern markets. Agrekon, 52(1), 68-86. http://dx.doi.org/10.1080/03031853.2013.778466

Hoang, N. T. M. (2011). Reality and economic solutions for promotting the export of Vietnam agricultural products in international integration. Master Thesis, Waseda University, Tokyo. https://dspace.wul.waseda.ac.jp/dspace/bitstream/2065/35064/1/ShokenBijinesuShuron_2011_9_HoangNga.pdf

Jabbar, M. A., \& Akter, S. (2008). Market and other factors affecting farm specific production efficiency in pig production in Vietnam. Journal of International Food \& Agribusiness Marketing, 20(3), 29-53. http://dx.doi.org/10.1080/08974430802157606

Kirsten, J., \& Sartorius, K. (2002). Linking agribusiness and small-scale farmers in developing countries: is there a new role for contract farming? Development Southern Africa, 19(4), 503-529. http://dx.doi.org/10.1080/0376835022000019428

Lapar, M. L. A., Binh, V. T., Son, N. T., Tiongco, M., Jabbar, M., \& Staal, S. (2006). The role of collective action in overcoming barriers to market access by smallholder producers: some empirical evidence from Northern Vietnam. Paper presented at the Workshop on" Collective Action and Market Access for Smallholders", 2-5, Cali, Colombia.

Louw, A., Jordaan, D., Ndanga, L., \& Kirsten, J. F. (2008). Alternative marketing options for small-scale farmers in the wake of changing agri-food supply chains in South Africa. Agrekon, 47(3), 287-308. http://dx.doi.org/10.1080/03031853.2008.9523801 
MacAulay, T. G. (2006). Farm Size and Land Use Changes in Vietnam Following Land Reforms, 57919, Australian Agricultural and Resource Economics Society.

Nga, N. T. D., Ha, N. T. T., \& Hai, P. G. (2011). Enhancing coordination in chicken production in Yen The district, Bac Giang province, Vietnam. Journal of International Society for Southeast Asian Agricultural Sciences (ISSAAS ), 17(2), 104-116.

Prowse, M. (2012). Contract farming in developing countries: a review: Agence Française de Développement A Savoir: Paris.

Saigenji, Y., \& Zeller, M. (2009). Effect of contract farming on productivity and income of small holders: The case of tea production in north-western Vietnam. Paper presented at the The International Association of Agricultural Economists Conference, Beijing, China, 16-22.

Thapa, G., \& Gaiha, R. (2011). Smallholder farming in Asia and the Pacific: Challenges and opportunities. IFAD con ference on New Directions for Smallholder Agri culture, 24, 25.

Tisdell, C. A. (2009). The survival of small-scale agricultural producers in Asia, particularly Vietnam: General issues illustrated by Vietnam's agricultural sector, especially its pig production: University of Queensland, School of Economics.

Ventana ${ }^{\circledR}$ (2011). Vensim program (Release http://www.ventanasystems.co.uk/vensim-6-1-released-may-2013/

Vo-Tong, X. (2002). Vietnam and the WTO. Washington: International Food \& Agricultural Trade Policy Council.

Wijk, S. v., \& Everaarts, A. (2007). The market for vegetables in North Vietnam. Wageningen: Wageningen University.

\section{(cc) EY}

This work is licensed under a Creative Commons Attribution 3.0 License. 